Supporting information for

\title{
Effects of international fuel trade on global sulfur dioxide emissions
}

Qirui Zhong ${ }^{\dagger}$, Huizhong Shen ${ }^{* \dagger}$, Xiao Yun ${ }^{\dagger}$, Yilin Chen ${ }^{\dagger *}$, Yu’ang Ren ${ }^{\dagger}$, Haoran Xu', Guofeng $\mathrm{Shen}^{\dagger}$, Jianmin $\mathrm{Ma}^{\dagger}$, Shu Tao ${ }^{\dagger}$

$\uparrow$ College of Urban and Environmental Sciences, Laboratory for Earth Surface Processes, SinoFrench Institute for Earth System Science, Peking University, Beijing 100871, China

+ School of Civil and Environmental Engineering, Georgia Institute of Technology, Atlanta 30318, USA

* Corresponding author: huizhong.shen@ce.gatech.edu

There are 4 figures and 4 tables. 


\section{Calculation of SCs and EFs}

A nation-level EF database for coal and oil was developed by considering international fuel trade. Table S2-S3 summarizes the SCs and ash contents (ACs) in hard coal (including anthracite, bituminous and coking coal) and crude oil for major fuel exporters, revealing substantial differences. To introduce the impacts of global fuel trade on fuel SCs, the trade data on hard coal and crude oil (which dominate the total traded coal and oil, respectively) were compiled for the 1980-2014 period for the Organization for Economic Co-operation and Development (OECD) from countries within the IEA ${ }^{1,2}$, and from the United Nation Comtrade Database ${ }^{3}$ for all the other countries. The calculated SCs and ACs were weighted to account for domestic production, import and export, as described by the following equations:

$$
S C=S C_{i} \times w_{i}+S C_{l} \times\left(w_{l}-w_{e}\right) ; A C=A C_{i} \times w_{i}+A C_{l} \times\left(w_{l}-w_{e}\right)
$$

where the subscripts $i, l$, and $e$ denote imported, domestically-produced, and exported fuels, respectively, and $w_{i}, w_{l}$, and $w_{e}$ represent the fractions of corresponding fuels in total fuel consumption. Note that $w_{i}+w_{l}-w_{e}=1$. The corresponding EF was calculated as follows:

$$
E F=S C \times(1-A C) \times(1-\gamma)
$$

where $\gamma$ is the sulfur removal rate of controlling measures corresponding to the type of control technology. For coal consumption, we adopted a technology split method based on promotion rates derived from previous reports and literatures (see Table S4), whereby we addressed the promotion of flue gas desulfurization (FGD) - a major technology used in power and industry for sulfur removal ${ }^{4}$. Given that crude oil is refined to produce various petroleum products, the SCs of petroleum products were calculated from the SCs of crude oil with consideration of the removal rates of sulfur during refining processes, which was quantified based on the total sulfur production from petroleum ${ }^{5}$ (Table S4).

For future projections up to 2030, the trends of fuel production and trading flows were derived from a 'Reference Scenario' developed by the Institute of Energy Economics Japan (IEEJ). This scenario assumed that no aggressive energy conservation or policies will be adopted in the near future ${ }^{6}$. Global total fuel consumption was also derived from IEEJ report and further assigned to 8 regions (i.e., East Asia, South and Central Asia, Southeast Asia and Oceania, Middle East and North Africa, Sub-Saharan Africa, Europe, North America, Latin America and the Caribbean) based on World Energy Council report ${ }^{7}$. These regional data were used to calculate future trends for countries within the region as a basis for the evaluation of future influences of fuel trade. 


\section{Fuel trade influence on SCs in the SS scenario}

SCs in hard coal and crude oil differed extensively by country (see Table S2, S3). With increasing globalization, the global fuel markets have expanded rapidly in recent years. For example, the global trade in hard coal in 2014 was over 7 times higher in volume than that of the late $1970 \mathrm{~s}^{1}$. Of the total consumption of hard coal and crude oil in some developed countries such as Japan and the United Kingdom, over $80 \%$ was imported rather than locally produced ${ }^{1}$.

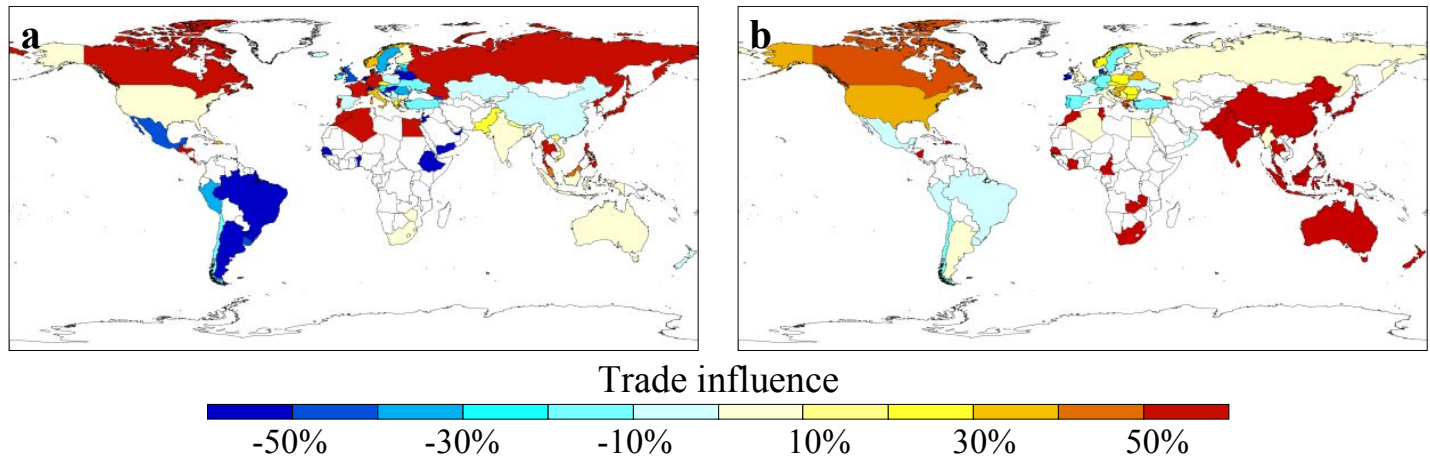

Fig. S1 The relative differences of national average SCs between real case and SS scenario for hard coal (a) and oil (b). The world shapefiles were obtained from Esri (ArcGIS Hub, Countries WGS84.

June 21

2015. http://www.arcgis.com/home/item.html?id=30e5fe3149c34df1ba922e6f5bbf808f).

Fig. S1 displays the influence of fuel trade on SCs by country in 2014 as a result of international fuel trade (Fig. S3a and S3c). Globally, the estimated SC in consumed hard coal was 5.4\% higher when considering the fuel trade than without considering the fuel trade. The influence of the fuel trade on SCs varied substantially by region. The most remarkable influence was found in Europe, where $58 \%$ of the domestically consumed hard coal was imported. In Germany, for example, nearly $30 \%$ of the hard coal was imported from the Netherlands, with a much higher SC $(\mathrm{SC}=2.1 \%)$ than that of domestically produced hard coal $(\mathrm{SC}=0.99 \%)^{1,8,9}$. This importing led to a net increase in SC of 34\% in Germany, and the overall increase was as high as 59\% when trade from all the other countries was considered. In the United Kingdom, over $50 \%$ of the domestically consumed hard coal was imported from Russia $(\mathrm{SC}=0.35 \%)$ and the United States $(\mathrm{SC}=1.7 \%)$, where the $\mathrm{SCs}$ were much lower than that of domestically produced hard coal $(\mathrm{SC}=3.9 \%)^{1,10,11}$. As a result, the SC of hard coal consumed in the United Kingdom decreased by $44 \%$ owing to the fuel trade, in sharp contrast to Germany. Although Asia imported the largest amount of hard coal among all continents, the imported hard coal only accounted for $17 \%$ of the total hard coal consumption, and over $85 \%$ of the imported hard coal was from the Asia-Pacific region (e.g., Australia, Indonesia and Vietnam), where the SCs were similar to the SCs of domestically produced coal in Asia countries. As a result, most Asian countries, including China and India, only showed moderate changes associated with the hard coal trade.

On average globally, $49 \%$ of domestically consumed crude oil was imported. This fraction was $145 \%$ higher than that of hard coal. As a result, the trade of crude oil led to an average increase of $65 \%$ in SCs of consumed crude oil. Among the seven regions, the Middle East was the largest exporting region, accounting for $44 \%$ of global crude oil exports, whereas the oil SC in the Middle East $(2.25 \%)$ was much higher than most other regions, which led to increases in SCs of crude oil in many countries that relied on the oil imported from the Middle East. For example, 33\% (171 Tg y-1) of the crude oil consumed in China (the SC of domestically-produced crude oil was $0.5 \%$ ) was imported from the Middle East, which doubled the SC of consumed crude oil in China 


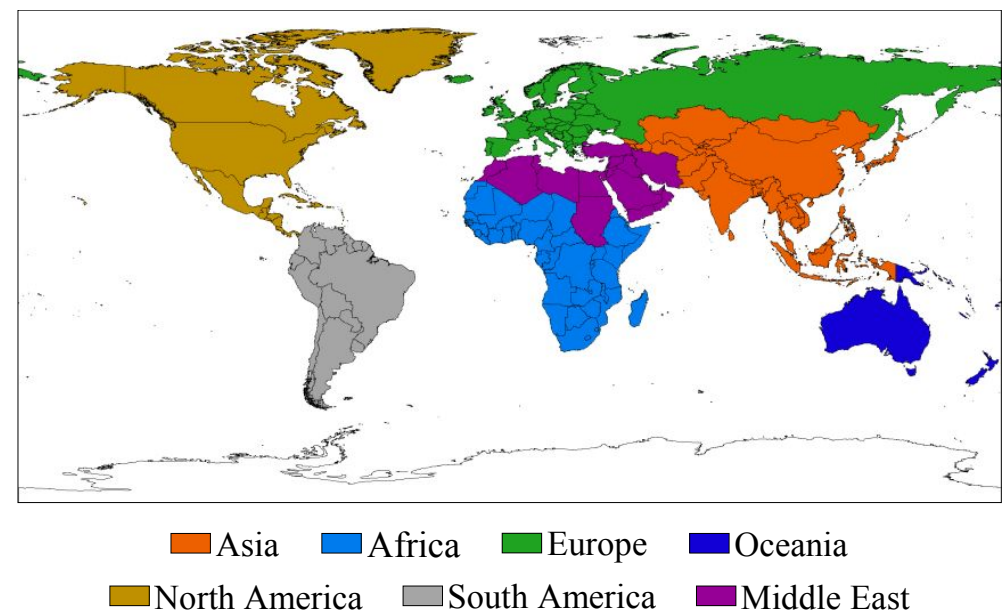

Fig. S2 Definition of the seven regions in this study. The color of each region is the same as that in Fig. S3. In addition to the six continents (i.e., Asia, Africa, Europe, Oceania, North America, and South America), the Middle East was illustrated separately due to its substantial global supply of crude oil with a significantly higher SC $(p<0.05)$. The world shapefiles were obtained from Esri (ArcGIS Hub, Countries WGS84. June 21, 2015. http://www.arcgis.com/home/item.html?id=30e5fe3149c34df1ba922e6f5bbf808f).
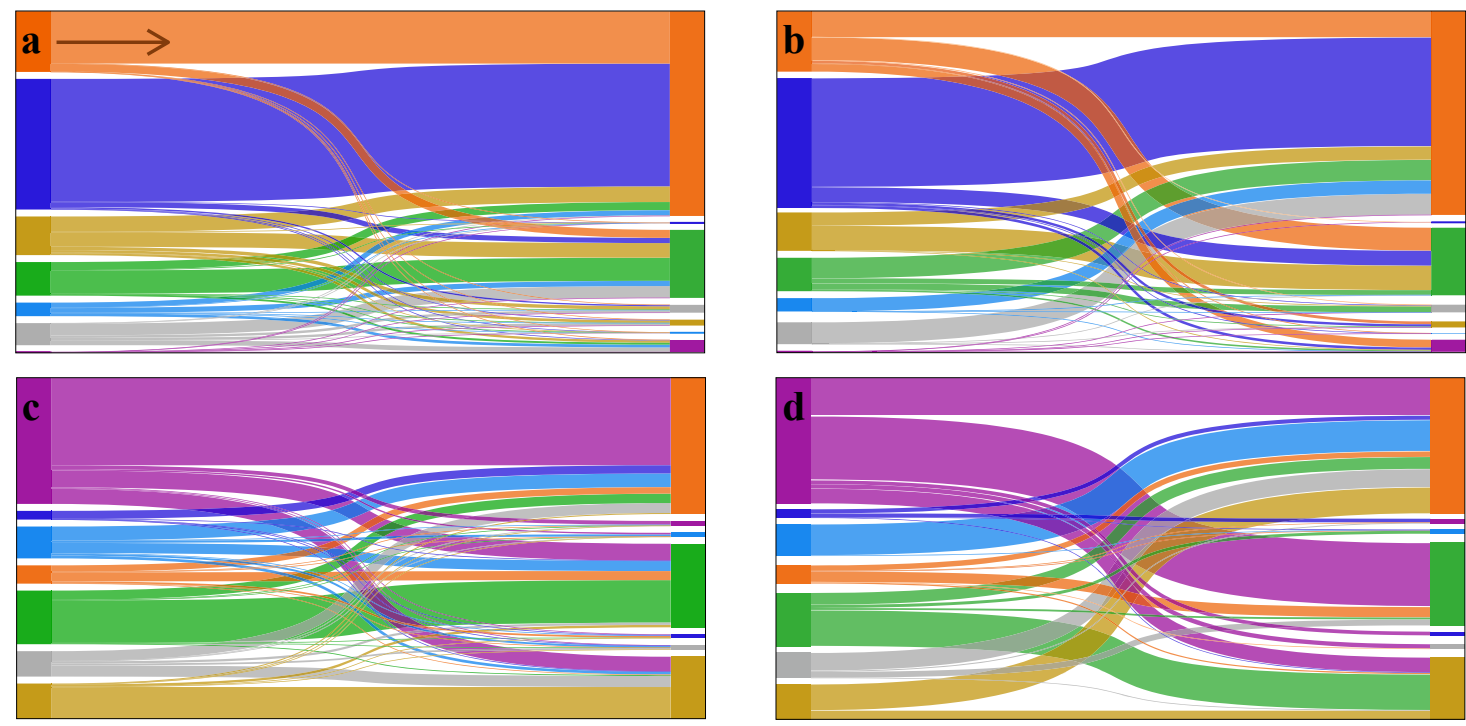

Asia $\square$ Africa $\square$ Europe $\square$ Oceania $\square$ North America $\square$ South America $\square$ Middle East

Fig. S3 Comparison between current international fuel trade flows (left panels) and trade flows for the minimum-emission (ME) scenario (right panels) for hard coal (a, b) and oil (c, d). Each trade flow diagram displays the trade volume from production region (left bars) to the trade destination (right bars) with different colors indicating different regions. The width of each flow is proportional to the magnitude of trade volume. The seven world regions are defined in Fig. S2. 

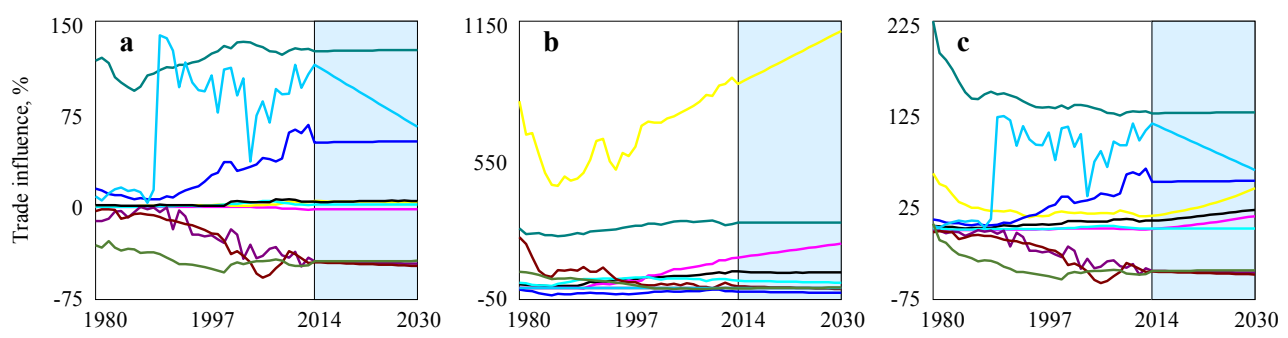

$\begin{array}{ll}\text { - } & \text { World } \\ - & \text { China } \\ - & \text { India } \\ - & \text { U. S. } \\ - & \text { Mexico } \\ - & \text { U. K. } \\ \text { - } & \text { Japan } \\ \text { - } & \text { Germany } \\ \text { - } & \text { Russia } \\ \text { - } & \text { Brazil }\end{array}$

Fig. S4 Relative influences of international trade on $\mathrm{SO}_{2}$ emissions from hard coals (a), oil (b), and both (c) for representative countries from 1980 to 2030. 
Table S1 Differences in the handling of sulfur contents (SCs) between previous studies and this study.

\begin{tabular}{|c|c|c|c|c|c|c|}
\hline Dataset & Year & Regions & Fuel type & Sulfur content data sources & This study & ref \\
\hline \multirow[t]{2}{*}{ EDGAR2.0 } & 1990 & World & Coal & $\begin{array}{l}\text { Regional-consumed SCs are used, SC of } 1.05 \% \text { is used for } \\
\text { all European countries. }{ }^{\text {a }}\end{array}$ & $\begin{array}{l}\text { Average SC for Europe is } 1.48 \% \pm 0.92 \% \text {, fuel } \\
\text { trade induces changes of SCs by }-90 \% \sim 148 \% \\
\text { for individual countries. }\end{array}$ & $\begin{array}{l}12, \\
13\end{array}$ \\
\hline & & & Oil & All countries use the same $\mathrm{SC}(1.88 \%){ }^{\mathrm{a}}$ & $\begin{array}{l}\text { SCs range from } 0.03 \% \sim 2.25 \% \text { for individual } \\
\text { countries. }\end{array}$ & \\
\hline EDGAR3.0 & $\begin{array}{l}1990- \\
1995\end{array}$ & World & $\begin{array}{l}\text { Fossil } \\
\text { fuels }\end{array}$ & $\begin{array}{l}\text { Same SCs used in EDGAR2.0 are used in EDGAR3.0. } \\
\text { Emission factors are recalculated based on CORINAIR95 } \\
\text { and NAPAP inventory for USA and Europe, respectively. }\end{array}$ & $\begin{array}{l}\text { SC increases by } 1 \% \text { for USA, }-51 \% \sim+182 \% \text { for } \\
\text { European countries, and }-25 \% \sim 51 \% \text { for all the } \\
\text { other countries from } 1990 \text { to } 1995 \text {, respectively. }\end{array}$ & 14 \\
\hline EDGAR4.3.2 & $\begin{array}{l}1970- \\
2012\end{array}$ & World & Coal & $\begin{array}{l}\text { Decreasing SCs are used for industrialized countries (North } \\
\text { America, Europe) due to implementation of regulation on } \\
\text { SCs. Detailed data and sources are not provided. }\end{array}$ & $\begin{array}{l}\text { SCs increase slightly }(\sim+2 \%) \text { in USA and } \\
\text { change by }-79 \% \sim+275 \% \text { for European countries } \\
\text { due to fuel trade. }\end{array}$ & 15 \\
\hline HTAP & $\begin{array}{l}2008- \\
2010\end{array}$ & World & Coal & $\begin{array}{l}\text { Country-specific SCs are used, and the variation of emission } \\
\text { factors are driven by the end-of-pipe measures. }\end{array}$ & $\begin{array}{l}\text { Fuel trade causes a change in SCs by }-84 \% \sim \\
+74 \% \text { for coal and by }-24 \% \sim+120 \% \text { for oil, } \\
\text { respectively. }\end{array}$ & 16 \\
\hline ASL & $\begin{array}{l}1850- \\
1990\end{array}$ & World & $\begin{array}{l}\text { Fossil } \\
\text { fuels }\end{array}$ & SC for each country is constant over time. & $\begin{array}{l}\text { Temporal-varied SCs of coal and oil are adopted } \\
\text { based on fuel trade. }\end{array}$ & 17 \\
\hline Smith et al., 2011 & $\begin{array}{l}1850- \\
2005\end{array}$ & World & $\begin{array}{l}\text { Fossil } \\
\text { fuels }\end{array}$ & $\begin{array}{l}\text { Assumed consumption-based SCs of fuels are used, which } \\
\text { are further adjusted according to existing global/regional } \\
\text { inventories. }\end{array}$ & $\begin{array}{l}\text { Fuel trade is considered to calculate spatial and } \\
\text { temporal SCs of fuels for all countries. }\end{array}$ & 18 \\
\hline Klimont et al., 2013 & $\begin{array}{l}2000- \\
2011\end{array}$ & World & $\begin{array}{l}\text { Fossil } \\
\text { fuels }\end{array}$ & $\begin{array}{l}\text { Consumption-based SCs of fuels are used based on GAINS } \\
\text { model. But the authors claim that estimates of SC still need } \\
\text { to be improved to reduce the uncertainties. }\end{array}$ & $\begin{array}{l}\text { Fuel trade is considered to calculate spatial and } \\
\text { temporal SCs of fuels for all countries. }\end{array}$ & 19 \\
\hline TNO-MACC_II & $\begin{array}{l}2003- \\
2009\end{array}$ & Europe & $\begin{array}{l}\text { Fossil } \\
\text { fuels }\end{array}$ & $\begin{array}{l}\text { Consumption-based SCs of fuels are used in the countries } \\
\text { constrained by CLRTAP. }\end{array}$ & $\begin{array}{l}\text { Fuel trade is considered to calculate spatial and } \\
\text { temporal SCs of fuels for all countries. }\end{array}$ & 20 \\
\hline Vestreng et al., 2007 & $\begin{array}{l}1980- \\
2004\end{array}$ & Europe & $\begin{array}{l}\text { Fossil } \\
\text { fuels }\end{array}$ & $\begin{array}{l}\text { Consumption-based SCs are reported by individual } \\
\text { countries and are validated within EMEP programme. }\end{array}$ & $\begin{array}{l}\text { Fuel trade is considered to calculate spatial and } \\
\text { temporal SCs of fuels for all countries. }\end{array}$ & 21 \\
\hline INTEX-B & $\begin{array}{l}2001- \\
2006\end{array}$ & Asia & Coal & $\begin{array}{l}\text { Constant consumption-based SCs are used. The emission } \\
\text { factors are driven by the regulation on FGD. }\end{array}$ & $\begin{array}{l}\text { Temporal-varied SCs of coal and oil are adopted } \\
\text { based on fuel trade. }\end{array}$ & 22 \\
\hline
\end{tabular}




\begin{tabular}{|c|c|c|c|c|c|c|}
\hline $\begin{array}{l}\text { Kato and Akimoto } \\
1992\end{array}$ & $\begin{array}{l}1975- \\
1987\end{array}$ & Asia & Coal & $\begin{array}{l}\text { Consumption-based SCs of fuels are adopted, which are } \\
\text { deduced by using a mean value weighted for domestic } \\
\text { production and import of each country. }\end{array}$ & $\begin{array}{l}\text { Temporal-varied weight of domestic and import } \\
\text { fuels are adopted based on fuel trade. }\end{array}$ & 23 \\
\hline Streets et al., 2001 & $\begin{array}{l}1985- \\
1997\end{array}$ & Asia & Coal & $\begin{array}{l}\text { SCs from RAINS-ASIA model are used with adjustment } \\
\text { based on a SC survey. }\end{array}$ & $\begin{array}{l}\text { Fuel trade is considered to calculate spatial and } \\
\text { temporal SCs of fuels for all countries. }\end{array}$ & 24 \\
\hline Klimont et al., 2009 & $\begin{array}{l}2000- \\
2030\end{array}$ & Asia & $\begin{array}{l}\text { Fossil } \\
\text { fuels }\end{array}$ & $\begin{array}{l}\text { Consumption-based SCs of fuels are used based on GAINS } \\
\text { model. }\end{array}$ & $\begin{array}{l}\text { Fuel trade is considered to calculate spatial and } \\
\text { temporal SCs of fuels for all countries. }\end{array}$ & 25 \\
\hline REAS & $\begin{array}{l}1980- \\
2008\end{array}$ & East Asia & $\begin{array}{l}\text { Fossil } \\
\text { fuels }\end{array}$ & $\begin{array}{l}\text { Consumption-based SCs of fuels are used but no temporal } \\
\text { variation is considered for most countries (e.g. India) }\end{array}$ & $\begin{array}{l}\text { SCs of oil in India increases by } 10 \% \text { due to oil } \\
\text { trade. }\end{array}$ & 26 \\
\hline Lu et al., 2011 & $\begin{array}{l}1996- \\
2010\end{array}$ & $\begin{array}{l}\text { China, } \\
\text { India }\end{array}$ & $\begin{array}{l}\text { Fossil } \\
\text { fuels }\end{array}$ & Consumption-based SCs of fuels are used. & $\begin{array}{l}\text { Fuel trade is considered to calculate spatial and } \\
\text { temporal SCs of fuels for all countries. }\end{array}$ & 27 \\
\hline Garg et al., 2001 & $\begin{array}{l}1990- \\
1995\end{array}$ & India & $\begin{array}{l}\text { Fossil } \\
\text { fuels }\end{array}$ & $\begin{array}{l}\text { Production-based SCs of fuels are adopted without temporal } \\
\text { trends. }\end{array}$ & $\begin{array}{l}\text { Fuel trade is considered to calculate spatial and } \\
\text { temporal SCs of consumed fuels for all countries. }\end{array}$ & 28 \\
\hline Lu et al., 2010 & $\begin{array}{l}2000- \\
2008\end{array}$ & China & $\begin{array}{l}\text { Fossil } \\
\text { fuels }\end{array}$ & Consumption-based SCs of fuels are used. & $\begin{array}{l}\text { Fuel trade is considered to calculate spatial and } \\
\text { temporal SCs of fuels for all countries. }\end{array}$ & 29 \\
\hline Zhao et al., 2008 & $\begin{array}{l}2005- \\
2020\end{array}$ & China & Coal & $\begin{array}{l}\text { Consumption-based SCs with no temporal variation are } \\
\text { used. }\end{array}$ & $\begin{array}{l}\text { Temporal-varied weight of domestic and import } \\
\text { fuels are adopted based on fuel trade. }\end{array}$ & 30 \\
\hline Zhao et al., 2011 & 2005 & China & Coal & $\begin{array}{l}\text { Consumption-based SCs are used. The authors conclude that } \\
\text { SCs contribute the most to } \mathrm{SO}_{2} \text { emission inventories. }\end{array}$ & $\begin{array}{l}\text { Fuel trade is considered to calculate spatial and } \\
\text { temporal SCs of fuels for all countries. }\end{array}$ & 31 \\
\hline $\begin{array}{l}\text { Streets and Waldhoff } \\
2000\end{array}$ & $\begin{array}{l}1990- \\
2020\end{array}$ & China & $\begin{array}{l}\text { Fossil } \\
\text { fuels }\end{array}$ & SCs from RAINS-ASIA model are used with adjustment. & $\begin{array}{l}\text { Fuel trade is considered to calculate spatial and } \\
\text { temporal SCs of fuels for all countries. }\end{array}$ & 32 \\
\hline
\end{tabular}

a. The original data is converted using a calorific value of $23.4 \mathrm{MJ} / \mathrm{kg}$ for coal and $47.3 \mathrm{MJ} / \mathrm{kg}$ for oil, respectively. 
Table S2 List of sulfur content (SC in \%) and ash content (AC in \%) in hard coal of major producing countries.

\begin{tabular}{llll|llll}
\hline Country ${ }^{a}$ & SC & AC & Ref. & Country & SC & AC & Ref. \\
\hline Australia & 1.1 & 5.03 & 33,34 & Latvia & 1.8 & 16.27 & 36 \\
Austria & 2.71 & 16.27 & 35 & Mexico & 3.5 & 8.14 & 50 \\
Belarus & 1.8 & 16.27 & 36 & Moldova & 3.1 & 38 & 29 \\
\hline Belgium & 1.35 & 16.27 & 37 & Monaco & 1.8 & 16.27 & 51 \\
\hline Canada & 0.67 & 5 & 38 & Mongolia & 0.7 & 10.28 & 38 \\
\hline China & 1.38 & 10.28 & 27,38 & Mozambique & 0.45 & 15.36 & 49 \\
\hline Colombia & 3.62 & 25.85 & 39,40 & Netherlands & 2.07 & 16.27 & 8,9 \\
\hline Czech Republic & 1.71 & 16 & 41 & New Zealand & 1.95 & 5.03 & 52 \\
\hline Denmark & 1.86 & 5.7 & 42 & North Korea & 0.32 & 10.28 & 38 \\
\hline Estonia & 1.9 & 16.27 & 43 & Norway & 1.8 & 16.27 & 36 \\
\hline Finland & 0.98 & 5.81 & 44,45 & Poland & 0.96 & 13.5 & 11 \\
\hline France & 0.8 & 16.27 & 8 & Portugal & 1.8 & 16.27 & 36 \\
\hline Germany & 0.99 & 9.48 & 46 & Romania & 1.7 & 39.8 & 53 \\
\hline Hungary & 4.84 & 32.2 & 47 & Russia & 0.35 & 11.45 & 11 \\
\hline India & 0.51 & 5.58 & 27 & South Africa & 0.19 & 15.15 & 53 \\
\hline Indonesia & 0.96 & 5.58 & 48 & South Korea & 0.74 & 10.28 & 38 \\
\hline Ireland & 3.87 & 7.6 & 10 & Ukraine & 3.13 & 8.16 & 33 \\
\hline Italy & 1.03 & 16.27 & 26 & United Kingdom & 3.87 & 7.6 & 53 \\
\hline Japan & 0.59 & 27.79 & 38 & United States & 1.69 & 11.27 & 46 \\
\hline Kazakhstan & 2.54 & 16.11 & 49 & Vietnam & 0.33 & 37.87 & 38 \\
\hline
\end{tabular}

a. Regional average was adopted if there is no data available for a specific coal producing country. 
Table S3 List of sulfur content (SC in \%) in crude oil for major producing countries.

\begin{tabular}{lll|lll}
\hline Country $^{a}$ & SC & Ref. & Country & SC & Ref. \\
\hline Algeria & 0.15 & 54 & Libya & 0.3 & 55 \\
\hline Angola & 0.29 & 55 & Lithuania & 1.7 & 54 \\
\hline Argentina & 0.41 & 55 & Mexico & 1.5 & 54 \\
Australia & 0.03 & 55 & Nigeria & 0.4 & 54 \\
\hline Azerbaijan & 1.7 & 54 & Norway & 0.1 & 23 \\
Canada & 0.42 & 23 & Oman & 2.25 & 54 \\
China & 0.5 & 23 & Qatar & 1.1 & 54 \\
Congo & 0.06 & 55 & Russia & 1.7 & 54 \\
Ecuador & 0.9 & 54 & Saudi Arabia & 2.25 & 54 \\
Egypt & 1.4 & 54 & Syria & 2.25 & 54 \\
Estonia & 1.7 & 54 & Turkey & 2.25 & 54 \\
Georgia & 1.7 & 54 & Ukraine & 1.7 & 54 \\
Indonesia & 0.15 & 54 & United Arab Emirates & 2.25 & 54 \\
Iran & 2.25 & 54 & United Kingdom & 0.4 & 54 \\
Iraq & 2.25 & 54 & United States & 0.7 & 54 \\
\hline Kazakhstan & 1.7 & 54 & Venezuela & 1.83 & 23 \\
Kuwait & 2.25 & 54 & Yemen & 2.25 & 54 \\
\hline Latvia & 1.7 & 54 & & & \\
\hline Regional average was adopted if there is no data available for a specific oil producing country.
\end{tabular}


Table S4 Technology split models for coal and oil consumed in power plants and industrial sector. A series of S-shaped curve were developed based on reported control data to characterize the temporal variations of promotion rate of FGD, which can be described as: $X(t)=X_{f}+\left(X_{0}-X_{f}\right) \exp \left[-\left(t-t_{0}\right)^{2} / 2 s^{2}\right]$, where $X_{0}, X_{f}$, and $X(t)$ were the ratio of a removal efficiency of beginning year $\left(t_{0}\right)$, final year, and a given year $(t)$, respectively, $s$ indicates the conversion ratio for the removal technology ${ }^{56}$.

\begin{tabular}{|c|c|c|c|c|c|c|}
\hline \multirow{2}{*}{ Fuel type } & \multirow{2}{*}{ Regions } & \multicolumn{4}{|c|}{ Parameters for S-shaped curve } & \multirow{2}{*}{ Ref. } \\
\hline & & $X_{0}$ & $X_{f}$ & $t_{0}$ & $s$ & \\
\hline \multirow{6}{*}{$\begin{array}{l}\text { Coal in } \\
\text { power } \\
\text { plants }{ }^{a}\end{array}$} & North America & 0 & 0.95 & 1970 & 19 & 57 \\
\hline & European countries & 0 & 0.98 & 1970 & 15 & 21 \\
\hline & Japan & 0.6 & 0.98 & 1975 & 5 & 58 \\
\hline & $\begin{array}{l}\text { Other developed } \\
\text { countries }\end{array}$ & 0 & 0.95 & 1970 & 26 & 21,58 \\
\hline & China & 0 & 0.95 & 1985 & 15 & 59 \\
\hline & $\begin{array}{l}\text { Other developing } \\
\text { countries }\end{array}$ & 0 & 0.95 & 1990 & 30 & 60 \\
\hline \multirow{5}{*}{$\begin{array}{l}\text { Oil in } \\
\text { power } \\
\text { plants } b\end{array}$} & North America & 0 & 0.98 & 1950 & 25 & 5 \\
\hline & European countries & 0 & 0.98 & 1950 & 30 & 5 \\
\hline & $\begin{array}{l}\text { Other developed } \\
\text { countries }\end{array}$ & 0 & 0.95 & 1960 & 35 & 5 \\
\hline & China & 0 & 0.9 & 1965 & 17 & 5 \\
\hline & $\begin{array}{l}\text { Other developing } \\
\text { countries }\end{array}$ & 0 & 0.85 & 1968 & 25 & 5 \\
\hline \multirow{6}{*}{$\begin{array}{l}\text { Coal in } \\
\text { industry } a\end{array}$} & North America & 0 & 0.95 & 1970 & 27 & 57 \\
\hline & European countries & 0 & 0.95 & 1970 & 30 & 21 \\
\hline & Japan & 0.7 & 0.98 & 1975 & 10 & 57 \\
\hline & $\begin{array}{l}\text { Other developed } \\
\text { countries }\end{array}$ & 0 & 0.95 & 1970 & 35 & 21,57 \\
\hline & China & 0 & 0.95 & 1985 & 15 & 59 \\
\hline & $\begin{array}{l}\text { Other developing } \\
\text { countries }\end{array}$ & 0 & 0.9 & 1990 & 40 & 60 \\
\hline \multirow{5}{*}{$\begin{array}{l}\text { Oil in } \\
\text { industry } b\end{array}$} & North America & 0 & 0.98 & 1950 & 17 & 5 \\
\hline & European countries & 0 & 0.98 & 1950 & 19 & 5 \\
\hline & $\begin{array}{l}\text { Other developed } \\
\text { countries }\end{array}$ & 0 & 0.95 & 1960 & 18 & 5 \\
\hline & China & 0 & 0.9 & 1965 & 17 & 5 \\
\hline & $\begin{array}{l}\text { Other developing } \\
\text { countries }\end{array}$ & 0 & 0.85 & 1968 & 25 & 5 \\
\hline
\end{tabular}

a. Removal efficiency of sulfur by FGD.

b. Different from coal consumption, sulfur in crude oil is largely removed during the petroleum refining as crude oil is not directly combusted in power and industrial activities. Considering that the sulfur recycled from petroleum refining is mainly used to produce sulfuric acid, S-shaped curves were developed according to the sulfur production from petroleum reported by USGS. 


\section{References}

(1). International Energy Agency. Coal Information. https://www.oecd-ilibrary.org/energy/data/ieacoal-information-statistics_coal-data-en (accessed 2018.10).

(2). International Energy Agency. Oil Information. https://www.oecd-ilibrary.org/energy/data/iea-oilinformation-statistics_oil-data-en (accessed 2018.10)

(3). United Nations Comtrade. https://comtrade.un.org/data/ (accessed 2018.10)

(4). Srivastava, R. K.; Jozewicz, W.; Singer, C. $\mathrm{SO}_{2}$ scrubbing technologies: A review. Environ. Prog. 2001, 20 (4), 219-227.

(5). U.S. Geological Survey. USGS Minerals Yearbook-Commodity Report. https://www.usgs.gov/centers/nmic/commodity-statistics-and-information (accessed 2018.10)

(6). The Institute of Energy Economics, Japan. IEEJ Outlook 2019: Energy transition and a thorny path for energy, environment and economy challenges. https://eneken.ieej.or.jp/data/8122.pdf (accessed 2019.04)

(7). World Energy Council. World energy scenarios: Composing energy future to 2050. https://www.worldenergy.org/publications/2013/world-energy-scenarios-composing-energyfutures-to-2050/ (accessed 2019.04).

(8). Klaassen, G. Trade-offs in sulfur emission trading in Europe. Environ. Resource Econ. 1995, 5, 191-219.

(9). Selsbo, P.; Almen, P.; Ericsson, I. Quantitative analysis of sulfur in coal by pyrolysis gas chromatography and multivariate data analysis. Energ. Fuel 1996, 10 (3), 751-756.

(10). Gorin, E.; Kulik, C. J.; Lebowitz, H. E. Deashing of coal liquefaction products via partial deasphalting .1. hydrogen-donor extraction effluents. Ind. Eng. Chem. Proc. Dd. 1977, 16 (1), 95102.

(11). Savolainen, K. Co-firing of biomass in coal-fired utility boilers. Appl. Energ. 2003, 74 (3-4), 369381.

(12). van Aardenne, J. A.; Dentener, F. J.; Olivier, J. G. J.; Goldewijk, C. G. M. K.; Lelieveld, J. A 1 degrees $\mathrm{x} 1$ degrees resolution data set of historical anthropogenic trace gas emissions for the period 1890-1990. Global Biogeochem. Cy. 2001, 15, (4), 909-928.

(13). Olivier, J. G. J.; Bouwman, A. F.; van der Maas, C. W. M.; Berdowski, J. J. M.; Veldt, C.; Bloos, J. P. J.; Visschedijk, A. J. H.; Zandveld, P. Y. J.; Haverlag, J. L. Description of EDGAR Version 2.0: A set of global emission inventories of greenhouse gases and ozone-depleting substances for all anthropogenic and most natural sources on a per country basis and on 1 degree $\times 1$ degree grid. 1996, RIVM, Bilthoven, RIVM Rapport 771060002.

(14). Olivier, J.G.J.; Berdowski, J.J.M.; Peters, J.A.H.W.; Bakker, J.; Visschedijk A.J.H.; Bloos J.-P.J. Applications of EDGAR. Including a description of EDGAR 3.0: reference database with trend data for 1970-1995. RIVM, Bilthoven. 2001, RIVM report no. 773301 001/ NOP report no. 410200051.

(15). Crippa, M.; Guizzardi, D.; Muntean, M.; Schaaf, E.; Dentener, F.; van Aardenne, J. A.; Monni, S.; Doering, U.; Olivier, J. G. J.; Pagliari, V.; et al., Gridded emissions of air pollutants for the period 1970-2012 within EDGAR v4.3.2. Earth Syst. Sci. Data 2018, 10, (4), 1987-2013.

(16). Janssens-Maenhout, G.; Crippa, M.; Guizzardi, D.; Dentener, F.; Muntean, M.; Pouliot, G.; Keating, T.; Zhang, Q.; Kurokawa, J.; Wankmuller, R.; et al., HTAP_v2.2: a mosaic of regional and global emission grid maps for 2008 and 2010 to study hemispheric transport of air pollution. Atmos. Chem. Phys. 2015, 15, (19), 11411-11432.

(17). Lefohn, A. S.; Husar, J. D.; Husar, R. B. Estimating historical anthropogenic global sulfur 
emission patterns for the period 1850-1990. Atmos. Environ. 1999, 33, (21), 3435-3444.

(18). Smith, S. J.; van Aardenne, J.; Klimont, Z.; Andres, R. J.; Volke, A.; Arias, S. D. Anthropogenic sulfur dioxide emissions: 1850-2005. Atmos. Chem. Phys. 2011, 11 (3), 1101-1116.

(19). Klimont, Z.; Smith, S. J.; Cofala, J. The last decade of global anthropogenic sulfur dioxide: 20002011 emissions. Environ. Res. Lett. 2013, 8, (1), 014003.

(20). Kuenen, J. J. P.; Visschedijk, A. J. H.; Jozwicka, M.; van der Gon, H. A. C. D. TNO-MACC_II emission inventory; a multi-year (2003-2009) consistent high-resolution European emission inventory for air quality modelling. Atmos. Chem. Phys. 2014, 14, (20), 10963-10976.

(21). Vestreng, V.; Myhre, G.; Fagerli, H.; Reis, S.; Tarrason, L. Twenty-five years of continuous sulphur dioxide emission reduction in Europe. Atmos. Chem. Phys. 2007, 7, (13), 3663-3681.

(22). Zhang, Q.; Streets, D. G.; Carmichael, G. R.; He, K. B.; Huo, H.; Kannari, A.; Klimont, Z.; Park, I. S.; Reddy, S.; Fu, J. S.; et al., Asian emissions in 2006 for the NASA INTEX-B mission. Atmos. Chem. Phys. 2009, 9, (14), 5131-5153.

(23). Kato, N.; Akimoto, H. Anthropogenic Emissions of $\mathrm{SO}_{2}$ and Nox in Asia - Emission Inventories. Atmos. Environ. 1992, 26, (16), 2997-3017.

(24). Streets, D. G.; Tsai, N. Y.; Akimoto, H.; Oka, K. Trends in emissions of acidifying species in Asia, 1985-1997. Water Air Soil Poll 2001, 130, (1-4), 187-192.

(25). Klimont, Z.; Cofala, J.; Xing, J.; Wei, W.; Zhang, C.; Wang, S.; Kejun, J.; Bhandari, P.; Mathur, R.; Purohit, P.; et al., Projections of $\mathrm{SO}_{2}$, NOx and carbonaceous aerosols emissions in Asia. Tellus B 2009, 61, (4), 602-617.

(26). Ohara, T.; Akimoto, H.; Kurokawa, J.; Horii, N.; Yamaji, K.; Yan, X.; Hayasaka, T. An Asian emission inventory of anthropogenic emission sources for the period 1980-2020. Atmos. Chem. Phys. 2007, 7, (16), 4419-4444.

(27). Lu, Z.; Zhang, Q.; Streets, D. G. Sulfur dioxide and primary carbonaceous aerosol emissions in China and India, 1996-2010. Atmos. Chem. Phys. 2011, 11, (18), 9839-9864.

(28). Garg, A.; Shukla, P. R.; Bhattacharya, S.; Dadhwal, V. K. Sub-region (district) and sector level $\mathrm{SO}_{2}$ and NOx emissions for India: assessment of inventories and mitigation flexibility. Atmos. Environ. 2001, 35, (4), 703-713.

(29). Lu, Z.; Streets, D. G.; Zhang, Q.; Wang, S.; Carmichael, G. R.; Cheng, Y. F.; Wei, C.; Chin, M.; Diehl, T.; Tan, Q. Sulfur dioxide emissions in China and sulfur trends in East Asia since 2000. Atmos. Chem. Phys. 2010, 10, (13), 6311-6331.

(30). Zhao, Y.; Wang, S. X.; Duan, L.; Lei, Y.; Cao, P. F.; Hao, J. M. Primary air pollutant emissions of coal-fired power plants in China: Current status and future prediction. Atmos. Environ. 2008, $42,(36), 8442-8452$.

(31). Zhao, Y.; Nielsen, C. P.; Lei, Y.; McElroy, M. B.; Hao, J. Quantifying the uncertainties of a bottom-up emission inventory of anthropogenic atmospheric pollutants in China. Atmos. Chem. Phys. 2011, 11, (5), 2295-2308.

(32). Streets, D. G.; Waldhoff, S. T. Present and future emissions of air pollutants in China: $\mathrm{SO}_{2}$, $\mathrm{NOx}$, and CO. Atmos. Environ. 2000, 34, (3), 363-374.

(33). Favas, G.; Jackson, W. R. Hydrothermal dewatering of lower rank coals. 2. Effects of coal characteristics for a range of Australian and international coals. Fuel 2003, 82 (1), 59-69.

(34). Goodarzi, F.; Hower, J. C. Classification of carbon in Canadian fly ashes and their implications in the capture of mercury. Fuel 2008, 87 (10-11), 1949-1957.

(35). Bechtel, A.; Butuzova, L.; Turchanina, O.; Gratzer, R. Thermochemical and geochemical characteristics of sulphur coals. Fuel Process Technol. 2002, 77, 45-52. 
(36). Spiro, P. A.; Jacob, D. J.; Logan, J. A. Global inventory of sulfur emissions with $1^{\circ} \times 1^{\circ}$ resolution. J. Geophys. Res. Atmos. 1992, 97 (D5), 6023-6036.

(37). Mior, R.; Mores, S.; Welz, B.; Carasek, E.; de Andrade, J. B., Determination of sulfur in coal using direct solid sampling and high-resolution continuum source molecular absorption spectrometry of the CS molecule in a graphite furnace. Talanta. 2013, 106, 368-374.

(38). Kato, N. Analysis of structure of energy consumption and dynamics of emissions of atmospheric species related to the global environmental change $\left(\mathrm{SOx}, \mathrm{NOx}\right.$, and $\left.\mathrm{CO}_{2}\right)$ in Asia. Atmos. Environ 1996, 30 (5), 757-785.

(39). Cardona, I. C.; Marquez, M. A. Biodesulfurization of two Colombian coals with native microorganisms. Fuel Process Technol. 2009, 90 (9), 1099-1106.

(40). Reyes, F.; Alcazar, G. A. P.; Barraza, J. M.; Bohorquez, A.; Tabares, J. A. Quantification of pyritic sulfur of one Colombian coal by Mossbauer spectroscopy. Hyperfine Interact. 2003, 148 (1-4), 31-38.

(41). Bouska, V.; Pesek, J. Quality parameters of lignite of the North Bohemian Basin in the Czech Republic in comparison with the world average lignite. Int. J. Coal Geol. 1999, 40 (2-3), 211-235.

(42). Pedersen, L. S.; Morgan, D. J.; vandeKamp, W. L.; Christensen, J.; Jespersen, P.; DamJohansen, K. Effects on SOx and NOx emissions by co-firing straw and pulverized coal. Energ. Fuel 1997, 11 (2), 439-446.

(43). Mastalerz, M.; Schimmelmann, A.; Hower, J. C.; Lis, G.; Hatch, J.; Jacobson, S. R. Chemical and isotopic properties of kukersites from Iowa and Estonia. Org. Geochem. 2003, 34 (10), 1419-1427.

(44). Sandelin, K.; Backman, R. Trace elements in two pulverized coal-fired power stations. Environ. Sci. Technol. 2001, 35 (5), 826-834.

(45). Heikkinen, R.; Laitinen, R. S.; Patrikainen, T.; Tiainen, M.; Virtanen, M. Slagging tendency of peat ash. Fuel Process Technol. 1998, 56 (1-2), 69-80.

(46). Casagrande, D. J.; Gronli, K.; Sutton, N. The distribution of sulfur and organic matter in various fractions of peat: origins of sulfur in coal. Geochim. Cosmochim. Ac. 1980, 44 (1), 25-32.

(47). Pettinau, A.; Dobo, Z.; Kontos, Z.; Zsemberi, A. Experimental characterization of a high sulfur Hungarian brown coal for its potential industrial applications. Fuel Process Technol. 2014, 122, 111.

(48). Belkin, H. E.; Tewalt, S. J.; Hower, J. C.; Stucker, J. D.; O'Keefe, J. M. K. Geochemistry and petrology of selected coal samples from Sumatra, Kalimantan, Sulawesi, and Papua, Indonesia. Int. J. Coal Geol. 2009, 77 (3-4), 260-268.

(49). Pak, Y. N.; Ponomaryova, M. V.; Pak, D. Y. Monitoring the sulfur content of coal. Coke Chem. 2016, 59 (1), 8-13.

(50). Lopez, M. T.; Zuk, M.; Garibay, V.; Tzintzun, G.; Iniestra, R.; Fernandez, A. Health impacts from power plant emissions in Mexico. Atmos. Environ. 2005, 39, (7), 1199-1209.

(51). Annals of the University of Petrosani Mining Engineering. Universitas Publishing House, Petroşani, România, 2007, ISSN 1454-9174.

(52). Weber, P. A.; Skinner, W.; Hughes, J. B.; Lindsay, P.; Moore, T. A. Source of Ni in coal mine acid rock drainage, West Coast, New Zealand. Int. J. Coal Geol. 2006, 67 (4), 214-220.

(53). Duliu, O. G.; Culicov, O. A.; Radulescu, I.; Cristea, C.; Vasiu, T. Major, trace, and natural radioactive elements in bituminous coal from Australia, Romania, Russia, South Africa and Ukraine: A comparative study. J. Radioanal. Nucl. Ch. 2005, 264 (3), 525-534.

(54). Casagrande, D. J. Sulphur in peat and coal. Coal and Coal-bearing Strata: Recent Advances 1987, 32, 87-105.

(55). Behrenbruch, P.; Dedigama, T., Classification and characterisation of crude oils based on distillation properties. J. Petrol. Sci. Eng. 2007, 57, (1-2), 166-180.

(56). Bond, T. C.; Bhardwaj, E.; Dong, R.; Jogani, R.; Jung, S.; Roden, C.; Streets, D. G.; Trautmann, N. M. Historical emissions of black and organic carbon aerosol from energy-related combustion, 1850-2000. Global Biogeochem. Cy. 2007, 21, GB2018.

(57). U.S. Energy Information Administration, Form EIA-860 detailed data with previous form data (EIA-860A/860B). https://www.eia.gov/electricity/data/eia860/ (accessed 2018.10). 
(58). Smith, S. J.; Pitcher, H.; Wigley, T. M. L. Future sulfur dioxide emissions. Climatic Change 2005, 73 (3), 267-318.

(59). National bureau of statistics of China. China statistical yearbook on environment. China Statistics Press, Beijing.

(60). Mittal, M. L.; Sharma, C.; Singh, R. Estimates of emissions from coal fired thermal power plants in India. 2012 International emission inventory conference 2012, 13-16. 